\title{
Diversity of Ni growth response and accumulation in Central-Eastern Mediterranean Odontarrhena (Brassicaceae) populations on and off serpentine sites
}

\author{
Isabella Bettarini $^{\mathrm{a}, \mathrm{b}, 1}{ }$, Cristina Gonnelli ${ }^{\mathrm{a}, 1}$, Federico Selvi $^{\mathrm{c}}$, Andrea Coppi $^{\mathrm{a}}$, Luigia Pazzagli ${ }^{\mathrm{b}}$, \\ Ilaria Colzi ${ }^{\text {a, } *}$ \\ ${ }^{a}$ Department of Biology, Università degli Studi di Firenze, via Micheli 1, 50121, Florence, Italy \\ ${ }^{\mathrm{b}}$ Department of Biomedical Experimental and Clinical Sciences, Università degli Studi di Firenze, viale Morgagni 50, 50134, Florence, Italy \\ ${ }^{\mathrm{c}}$ Department of Agriculture, Food, Environment and Forestry, Laboratories of Botany, Università degli Studi di Firenze, P. le Cascine 28, I-50144, Florence, Italy
}

\section{A R T I C L E I N F O}

\section{Keywords:}

Trace metals

Hyperaccumulation

Tolerance

Hormesis

Alyssum

\begin{abstract}
A B S T R A C T
Nickel response and accumulation were analyzed in 12 populations from seven Central-Eastern Mediterranean Odontarrhena taxa on and off serpentine sites to test the presence of metal-induced growth stimulation and its relationship with tolerance and plant Ni concentration. Seedlings were cultivated in hydroponics with increasing $\mathrm{NiSO}_{4}$ concentrations to obtain dose-response curves and to evaluate Ni levels in roots and shoots. In all the accessions, a metal stimulatory effect on growth was present in the low-dose zone and significantly fitted the Brain-Cousens hormetic model. Accessions showed broad variation in tolerance, with the most tolerant plants requiring the highest $\mathrm{Ni}$ concentrations in the culture medium for optimal growth. Significant differences were also detected in plant Ni concentrations and a positive relationship was found between tolerance and accumulation. The serpentine and non-serpentine populations of $O$. chalcidica were similarly capable of hyperaccumulation, suggesting this ability to a be a species-wide trait. In the case of $O$. muralis, a species that preferentially avoids serpentine soils, the two populations from non-serpentine sites showed the same Nienhanced growth of the serpentine accessions of the other species investigated here, but only at the lowest concentration, and reached shoot Ni amounts approaching the Ni hyperaccumulation threshold. Therefore, in Odontarrhena the capacity to tolerate and accumulate Ni could be considered a specieswide trait in all the serpentine taxa, both endemic and facultative. Regarding the metal concentration showed by the accessions in nature, neither Ni levels in the field-collected plants nor those in their natural soils of origin were related to $\mathrm{Ni}$ tolerance. On the other hand, $\mathrm{Ni}$ accumulation capacity appeared as the main driving factor for the metal concentration in the plants in their native habitats.
\end{abstract}

\section{Introduction}

Hyperaccumulating plants can accumulate metals to exceptionally high concentrations in their above-ground parts (Baker and Brooks, 1989; Reeves and Baker, 2000). In the case of $\mathrm{Ni}$, the minimum threshold value is considered $1000 \mu \mathrm{g}$ metal $\mathrm{g}^{-1}$ shoot dry weight (Brooks et al., 1977). With some 530 taxa, Ni-hyperaccumulators are the most common group of metal-hyperaccumulating plants, probably due to the worldwide extensive occurrence of the metalliferous substrates where they live (Krämer, 2010; van der Ent et al., 2013; Wójcik et al., 2017; Reeves et al., 2018). Such plants populate serpentine soils, which are characterized by high levels of $\mathrm{Ni}$, Co and $\mathrm{Cr}$, low levels of nutrients and a high $\mathrm{Mg} / \mathrm{Ca}$ ratio (Brown et al., 1987; Gonnelli and Renella, 2012). The first Ni-hyperaccumulating plant discovered belongs to the genus Odontarrhena (O. bertolonii Desv., until recently known as Alyssum bertolonii; Minguzzi and Vergnano, 1948), representing the most diverse group of Ni-hyperaccumulators in Europe (Reeves et al., 1983; Peer et al., 2006; Nkrumah et al., 2016). This genus includes about 60 species

\footnotetext{
* Corresponding author.

E-mail addresses: isa.betta@libero.it (I. Bettarini), cristina.gonnelli@unifi.it (C. Gonnelli), federico.selvi@unifi.it (F. Selvi), andrea.coppi@unifi.it (A. Coppi), luigia.pazzagli@unifi.it (L. Pazzagli), ilaria.colzi@unifi.it (I. Colzi).

1 These two authors contributed equally to the work.
} 
capable to accumulate metals (Reeves et al., 2018) out of a total of approximately 90 species distributed from the Iberian Peninsula to Iran and adjacent regions (Španiel et al., 2015).

Such Ni-hyperaccumulators are often obligate endemics of Ni-rich serpentine outcrops, while more rarely they grow either on or off these substrates with, respectively, hyperaccumulating and nonaccumulating populations (Wójcik et al., 2017). So far, the only known exception is $O$. sibirica, the serpentine populations of which are apparently the only ones in the genus incapable of metal hyperaccumulation (Bettarini et al., 2020). Odontarrhena taxa and populations have been studied as indicators in prospecting for metals (Brooks, 1983), as model systems to investigate the mechanisms of metal-hyperaccumulation (Verbruggen et al., 2009; Deng et al., 2018) and, more recently, as resources for practical applications of metal phytoextraction and agromining (van der Ent et al., 2015; Kidd et al., 2018).

The Balkan countries and Italy can provide a rich plant material for investigating various Ni-hyperaccumulation issues thanks to the wide distribution of Odontarrhena populations of different taxa growing on and off serpentine soils. Recent studies showed significant variability in element concentrations in Balkan plants and relative outcrops of origin (Bani et al., 2010, 2013, Bettarini et al., 2019), thus offering a unique opportunity for research on the biology of Ni-hyperaccumulation.

One of the poorly investigated aspects of hyperaccumulators is their growth response in the presence of $\mathrm{Ni}$, despite the general assumption that these plants display a higher basal requirement of the hyperaccumulated metal (Pollard et al., 2002; Manara et al., 2020). In the Zn-accumulator species Arabidopsis halleri and Noccaea caerulescens, a peculiar request of $\mathrm{Zn}$ for growth was shown to be associated with a depletion of the metal cytosolic pool caused by the hyperaccumulation mechanisms themselves at too low external doses (Talke et al., 2006; Hanikenne et al., 2008). At present, there are many reports in which a Ni-stimulatory effect at low metal doses was observed in some Odontarrhena hyperaccumulators (see for example Krämer et al., 1996; Küpper et al., 2001; Whiting et al., 2003, Galardi et al. 2007, Centofanti et al., 2013). However, the above studies were focused on the physiological mechanisms of hyperaccumulation, neglecting or only marginally discussing the growth responses. In addition, such studies were based on populations of a single species or, in other cases, on one population of two or three distantly related species, sometimes of doubtful taxonomic identification (Cecchi et al., 2018). A recent investigation on $O$. sibirica provided a more detailed analysis of the Ni-induced stimulation of growth at low metal concentrations (Bettarini et al., 2020). In such study, the metal response in terms of root and shoot growth was found to fit the Brain-Cousens hormetic model (Brain and Cousens, 1989) in serpentine populations of both $O$. sibirica and $O$. chalcidica. Actually, the phenomenon of hormesis is the unexpected positive effect of non-essential ions at low doses in plants (Poschenrieder et al., 2013), whereas such growth stimulation can be predicted in the case of micronutrients, such as Ni. Nonetheless, hormetic models, unlike the logistic ones, calculate not only the tolerance parameters but also the quantitative descriptors of the stimulating effect, such as the maximum stimulation dose and the maximum mean response (Brain and Cousens, 1989), helping to unravel new aspects of hyperaccumulation.

In this work, twelve populations from seven Central-Eastern Mediterranean Odontarrhena taxa on and off serpentine sites were studied in controlled conditions for a quantitative analysis of Ni growth response and accumulation in the relevant plant compartments, namely in shoots and both root symplast and apoplast. Five of these taxa are obligate serpentine endemics, most of them analyzed here for the first time, while one occurs on either serpentine and non-serpentine soils (facultative, $O$. chalcidica) and one, $O$. muralis, is mainly found on non-serpentine soils (Hartvig, 2002). Although the latter has long been regarded as a Ni-hyperaccumulator (Verbruggen et al., 2009, Deng et al., 2018), most of the material under this name used in previous studies is likely to belong to the closely related $O$. chalcidica (Cecchi et al., 2018, Coppi et al., 2020). Based on a careful identification of the plant accessions collected in the field, we could reliably compare for the first time the Ni-phenotype in these two often confused species, studying serpentine and non-serpentine populations of $O$. chalcidica and typical non-serpentine populations of $O$. muralis.

The increasing number of studies on metal hyperaccumulation in plants shows the current relevance of this topic in the field of base plant physiology and for biotechnological applications (Kidd et al., 2018). Identifying the taxa and populations with different tolerance and accumulation potential is a primary step for both a better understanding of the mechanisms and the success of the practical applications. Accordingly, the primary aims of this paper were: i) to investigate whether there is a Ni stimulating effect in the low-dose zone significantly fitting to a hormetic model in all the examined accessions of Odontarrhena, including those from non-serpentine sites, ii) to assess possible differences in Ni tolerance and accumulation among the accessions, evaluating also their relationship with the metal concentration in the original soils, iii) to test the hypothesis that the accessions with the higher accumulation capacity are those requiring the higher $\mathrm{Ni}$ concentrations for their optimal growth, considering that $\mathrm{Ni}$ hyperaccumulation mechanisms could be responsible for metal deficiency in the cytosol in the low-dose zone.

\section{Materials and methods}

\subsection{Plant material and growth conditions}

Seeds were collected by the authors from native populations of the following taxa: $O$. bertolonii (Italy, serpentine soil), O. chalcidica (Albania and Greece, both serpentine and non-serpentine soil), $O$. decipiens (Albania, serpentine), O. moravensis (Albania, serpentine), O. muralis (Romania and Greece, non-serpentine soil), O. rigida (Albania, serpentine) and O. smolikana (Albania, serpentine). Identification was based on Hartvig (2002) and the recent taxonomic revision of the Albanian taxa by Cecchi et al. (2018). For each population, seeds were collected from at least 10 randomly selected plants. The number of analyzed populations for each species was uneven depending on the different extent of the distribution ranges of the species and the availability of mature seeds. Collection sites, accession codes, soil type and Ni concentration in the native soils and field collected plants are indicated in Table 1 (according to Bettarini et al. 2019 for the Albanian accessions). Regarding samples not analyzed in Bettarini et al. (2019), Ni concentration in O. chalcidica population Oc.12, O. bertolonii and O. muralis, as well as in their respective soils of origin, were determined by the same protocol (Bettarini et al. 2019).

Seeds were sown in peat soil and 6-week-old seedlings were then transferred to hydroponic cultures, in 1-L polyethylene pots (one plant per pot) containing a modified half-strength Hoagland's solution (Hoagland and Arnon, 1950) in milliQ-water (Millipore, Billerica, MA, USA) buffered with $2 \mathrm{mM}$ 2-morpholinoethanesulphonic acid, $\mathrm{pH}$ 5.5, adjusted with $\mathrm{KOH}$. Background Ni concentration in the growing medium was about $0.1 \mu \mathrm{M}$ and this was considered as the control condition as in Bettarini et al. (2020). Nutrient solutions were changed weekly and plants were grown in a growth chamber $\left(24 / 16^{\circ} \mathrm{C}\right.$ day/night; light intensity $100 \mu \mathrm{mol} \mathrm{m} \mathrm{m}^{-2} \mathrm{~s}^{-1}$, 16-h (day) photoperiod; relative humidity $60-65 \%)$. After 3 weeks of pre-culture, plants of homogeneous size were chosen and treated as in Bettarini et al. (2020): root length of each plant was measured and subsequently plants were exposed for 7 days to a series of $\mathrm{NiSO}_{4}$ concentrations $(0,50,100,250,500,100,2000,3000$ $\mu \mathrm{M}, 12$ plants per treatment), in a background solution of the same composition as the pre-culture solution. The applied Ni concentrations were in the range of toxicity for plants not adapted to metal excess ( 5 $\mu \mathrm{M}$, Marschner, 1995) and were previously proved to be adequate for serpentine plants of Odontarrhena (Bettarini et al., 2020). After 7 days of growth, root length of all plants was measured again to assess the increment. 
Table 1

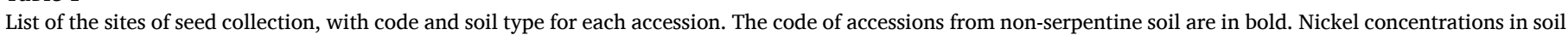

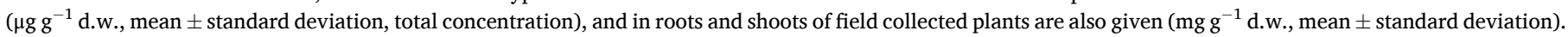

\begin{tabular}{|c|c|c|c|c|c|c|}
\hline Accession & Site of collection & Code & Soil type & [Ni] soil & [Ni] shoot & {$[\mathrm{Ni}]$ root } \\
\hline \multirow[t]{5}{*}{ O. chalcidica (Janka) Španiel et al. } & Shkodër (ALB) & Oc. 3 & serpentine & $4788 \pm 107$ & $13.2 \pm 1.9$ & $3.1 \pm 0.3$ \\
\hline & Elbasan, Shushice, (ALB) & Oc. 5 & serpentine & $2917 \pm 153$ & $15.2 \pm 3.9$ & $2.9 \pm 0.7$ \\
\hline & Prrënjas, Mt. Shebenik (ALB) & Oc.6 & serpentine & $3460 \pm 75$ & $19.2 \pm 3.2$ & $3.7 \pm 0.7$ \\
\hline & Pogradeč (ALB) & Oc. 8 & serpentine & $3008 \pm 94$ & $19.3 \pm 2.1$ & $3.5 \pm 0.9$ \\
\hline & Gomati (GRE) & Oc.12 & schist & $69 \pm 19$ & $6.4 \pm 1.2$ & $1.0 \pm 0.3$ \\
\hline O. decipiens (Nyár.) L.Cecchi \& Selvi & Kruje, Qafë Shtamë (ALB) & Od.4 & serpentine & $3860 \pm 120$ & $14.6 \pm 3.3$ & $1.8 \pm 0.4$ \\
\hline O. moravensis (F.K.Mey.) L.Cecchi \& Selvi & Korçë, Voskopoje (ALB) & Om.2 & serpentine & $1447 \pm 21$ & $12.4 \pm 3.3$ & $0.8 \pm 0.2$ \\
\hline O. rigida (Nyár.) L.Cecchi \& Selvi & Librazhd, Pishkash (ALB) & Or.3 & serpentine & $3125 \pm 87$ & $10.6 \pm 2.8$ & $1.7 \pm 0.6$ \\
\hline O. smolikana Nyár.subsp. glabra (Nyár) L. Cecchi \& Selvi & Kruje, Qafë Shtamë (ALB) & Os.1 & serpentine & $3182 \pm 141$ & $8.2 \pm 1.2$ & $0.9 \pm 0.3$ \\
\hline O. bertolonii (Desv.) Jord. \& Fourr. & Casenovole, Grosseto (ITA) & $\mathrm{Ob}$ & serpentine & $1900 \pm 97$ & $11.5 \pm 0.9$ & $0.8 \pm 0.1$ \\
\hline \multirow[t]{2}{*}{ O. muralis (Waldst. \& Kit.) Endl. } & Deva (Hunedoara) (ROU) & Omu.1 & Acid volcanic rock & $10 \pm 3$ & $0.05 \pm 0.01$ & $0.01 \pm 0.005$ \\
\hline & Paranesti (GRE) & Omu.2 & granite & $46 \pm 6$ & $0.21 \pm 0.05$ & $0.02 \pm 0.01$ \\
\hline
\end{tabular}

\subsection{Nickel accumulation in roots and shoots}

After 7 days of treatment, plants were rinsed with milliQ-water and the roots of half of the samples were carefully washed with $10 \mathrm{mM} \mathrm{Pb}$ $\left(\mathrm{NO}_{3}\right)_{2}$ at $4{ }^{\circ} \mathrm{C}$ for $30 \mathrm{~min}$ to desorb metals adhering to the root cell wall, as in Bazihizina et al. (2015). Shoots and roots were dried at $70{ }^{\circ} \mathrm{C}$ for $24 \mathrm{~h}$ and then weighed and $\mathrm{HNO}_{3}$-mineralised in a microwave system (Mars 6, CEM). Nickel concentration was determined with an atomic absorption spectrophotometer model PinAAcle 500 (PerkinElmer, Waltham, Massachusetts, USA). Apoplastic Ni concentration in roots was calculated as the difference between metal concentration in non-desorbed and desorbed samples.

\subsection{Statistics}

The experimental design was a randomized complete block, where treatments were replicated once within each block. The pots were randomly assigned to table space and were randomised every week.

Analysis of the growth response to Ni treatment was performed by fitting the experimental data points to the Brain-Cousens model. The increment in root length was measured as response variable for all tested accessions, while the $\mathrm{Ni}$ concentration of the growth medium was considered as the predictor variable. The Brain-Cousens model allows to validate the presence of significant hormetic effect and to estimate the following parameters: the external maximum stimulation dose ( $\left.\mathrm{MSD}_{\mathrm{ext}}\right)$, the maximum mean response (MAX, necessary for a reliable calculation of the percentage of the hormetic effect as [100*(MAX-length increment in control condition)/length increment in control condition], here named hormetic percentage $=\mathrm{HP}$ ) and the half-maximal effective external concentration $\left(\mathrm{EC}_{50 \mathrm{ext}}\right)$. Basing on data of $\mathrm{Ni}$ concentrations accumulated in the root symplast, instead of the $\mathrm{Ni}$ concentrations present in the culture medium, the Brain-Cousens model was used to estimate also the internal maximum stimulation dose $\left(\mathrm{MSD}_{\text {int }}\right)$ and the half-maximal effective internal concentration ( $\left.\mathrm{EC}_{50 \text { int }}\right)$. This last parameter $\left(\mathrm{EC}^{2} 0_{\text {int }}\right)$ was used as an index of the accumulation capacity as in Galardi et al. (2007), Colzi et al. (2014) and Adamidis et al. (2014). The drc package (Ritz et al., 2015) as implemented in R Studio version $\mathrm{R}$ 3.4.3 ( $R$ Core Team 2017) was used to fit the curve of concentration-response data.

The significance of differences between the means was analyzed by one-way and two-way ANOVA followed by a HSD-Tukey test for post-hoc comparisons using GraphPad Prism 7 (GraphPad Software, San Diego, CA).

Linear regression analyses were performed to investigate the relationships between the parameters obtained by data fitting and between these and the metal concentrations in native soils and plants. Although results of the regression analysis could be affected by the use of total soil Ni concentration, we consider this concentration as the best proxy of the metal fraction available to the plants, since the latter can vary depending on a number of site-specific factors that are difficult to identify.

\section{Results}

3.1. Ni concentration in soil and plants of non-serpentine O. chalcidica, $O$. muralis and serpentine $O$. bertolonii

Soil samples from the serpentine outcrop of Casenovole in Central Italy, the site of origin of $O$. bertolonii plants $(\mathrm{Ob})$, showed much higher Ni levels (about $1900 \mu \mathrm{g} \mathrm{g}^{-1}$ d.w.) than those from the non-serpentine sites of Gomati, Paranesti (Greece) and Deva (Romania; Table 1). Concerning plants, Oc.12 (O. chalcidica) and Ob samples displayed higher amounts of $\mathrm{Ni}$ (in shoots about 6 and $11 \mathrm{mg} \mathrm{g}^{-1} \mathrm{~d} . \mathrm{w}$, respectively) in contrast to the very low levels of O.muralis accessions Omu.1 and Omu.2. In all samples, Ni accumulation in shoots was higher than in roots.

\subsection{Plant growth}

Root length variations of the Odontarrhena accessions exposed to increasing $\mathrm{NiSO}_{4}$ concentrations are illustrated in Fig. 1 as increment after 7 days of treatment. Generally, plants showed a significantly higher growth increment in respect to control conditions in the low-dose zone, which was variable depending on metal doses and accessions. Accessions Oc.3, Oc.6, Oc.8, Os.1 and Ob displayed significant increments up to the treatment $500 \mu \mathrm{M} \mathrm{NiSO}_{4}$. At the highest metal concentrations, there was a reduction in root length increment, again at different $\mathrm{Ni}$ treatments for the different accessions. For instance, the Od.4 plants displayed a significant negative effect of $\mathrm{Ni}$ in respect to control conditions already at $250 \mu \mathrm{M}$ and, at the other extreme, the Os.1 plants only starting from $2000 \mu \mathrm{M}$. The accessions Omu.1 and Omu. 2 did not survive at the two highest concentrations. Two-way ANOVA showed significant interspecific variation in root elongation in response to $\mathrm{Ni}$ treatments (Table 2).

The Brain-Cousens hormetic model provided a significant fitting; the lack-of-fit test gave p-values ranging from 0.053 to 0.6674 (Table 3a), thus validating the model for all the studied accessions. Plants showed different values for the parameters calculated by the data fitting (Table 3a). MSD ranged from 32 for Omu.1-410 $\mu \mathrm{M} \mathrm{NiSO}_{4}$ for Oc. 6 and HP from 20 for Or3 to $86 \%$ for Ob. EC50 ${ }_{\text {ext }}$ ranged from ca. 240 to ca. $1900 \mu \mathrm{M} \mathrm{NiSO}_{4}$ for Od.4 and Oc.6, respectively, and significant variation was found among the accessions (Table $3 \mathrm{~b}$ ). Plants of the Oc.6 accession showed a significantly higher value, together with Oc.12, while Od.4, Omu.1 and Omu. 2 significantly lower ones in respect to the EC50 $0_{\text {ext }}$ of the other samples.

Relationships between the estimated values of $\mathrm{MSD}_{\text {ext }}$ and the mean values of $\mathrm{EC}_{50 \mathrm{ext}}$ were significant $(\mathrm{r}=0.663, \mathrm{p}<0.05)$, whereas no relation was found between all the calculated parameters and the concentrations of $\mathrm{Ni}$ in the native soils and plant samples (Table 4). 


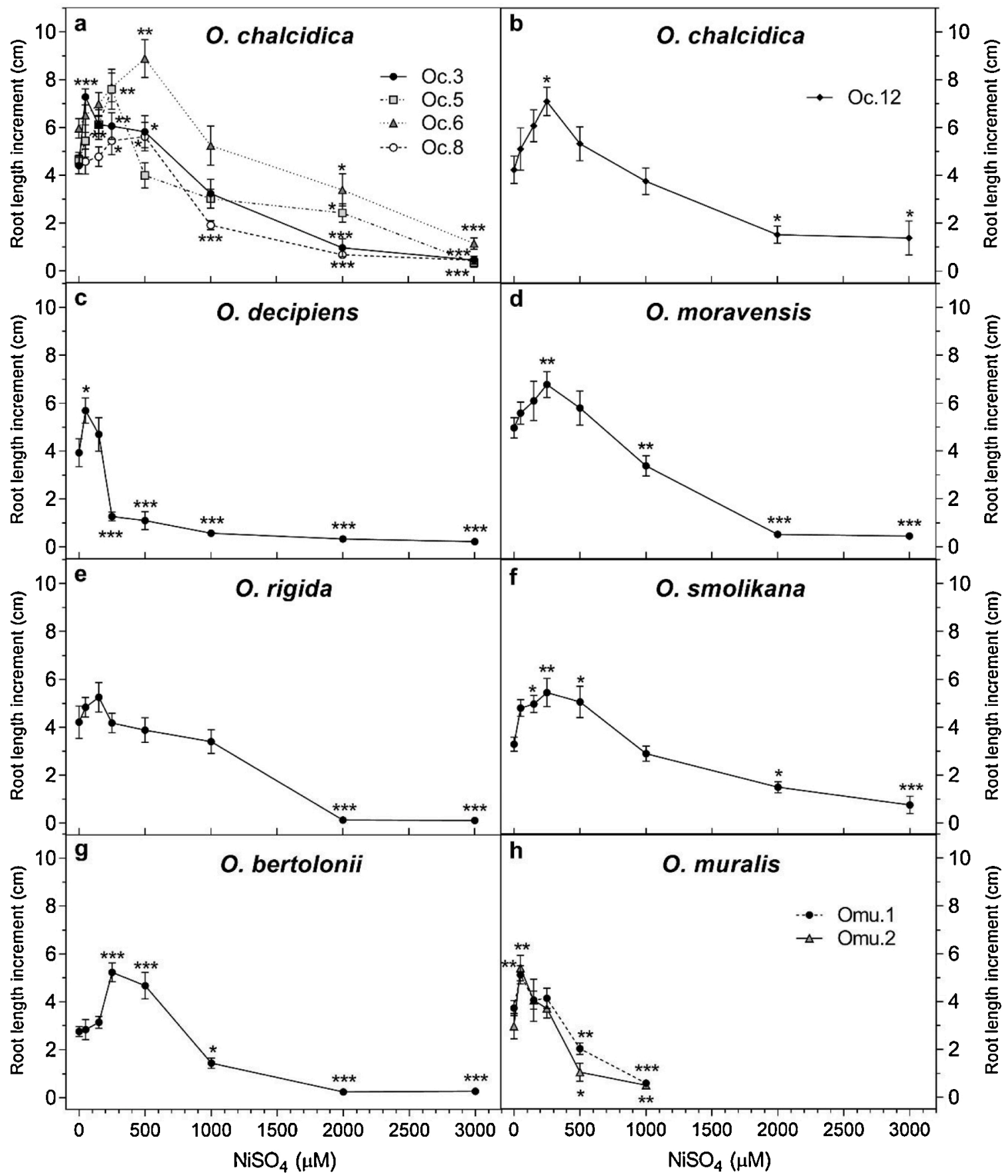

Fig. 1. Increment in root length $(\mathrm{cm})$ in 12 Odontarrhena accessions treated with increasing concentrations of $\mathrm{NiSO}_{4}$. Increment was calculated subtracting length values at the beginning of the treatment to values at the end of the treatment. a) $O$. chalcidica from serpentine soil, b) $O$. chalcidica from non-serpentine soil, c) $O$. decipiens, d) O. moravensis, e) $O$. rigida, f) $O$. smolikana, g) $O$. bertolonii, h) $O$. muralis. Asterisks indicate the significant differences in root length within each accession according to the Tukey's test. $*<0.05, * * \mathrm{p}<0.01,{ }^{* * *}<0.001$. Values are means of 12 replicates \pm standard deviation.

Table 2

Two-way ANOVA results for root length increment in the 12 accessions of Odontarrhena treated with eight $\mathrm{NiSO}_{4}$ concentrations for seven days.

\begin{tabular}{llllll}
\hline ANOVA table & SS & DF & MS & F (DFn, DFd) & P value \\
\hline Accessions & 1194 & 11 & 108.5 & $\mathrm{~F}(11,1056)=496.9$ & $\mathrm{P}<0.0001$ \\
Ni treatments & 3948 & 7 & 564 & $\mathrm{~F}(7,1056)=2583$ & $\mathrm{P}<0.0001$ \\
Interaction & 810.9 & 77 & 10.53 & $\mathrm{~F}(77,1056)=48.22$ & $\mathrm{P}<0.0001$ \\
Residual & 230.6 & 1056 & 0.218 & & \\
\hline
\end{tabular}

\subsection{Nickel accumulation}

$\mathrm{Ni}$-concentration in roots and shoots increased with increasing external Ni concentration in all accessions. Shoots showed the highest values, followed by the symplastic fraction of the roots and then by the apoplastic one (Tables 5-7). However, accessions differed significantly in root and shoot $\mathrm{Ni}$ accumulation. For most treatments, those with the highest $\mathrm{Ni}$ concentrations in the root apoplast were Oc.3 and Oc.6, whereas Oc. 6 and Oc. 8 showed the highest levels in the root symplast. In shoots, plants of Oc. 8 and Om.2 accessions reached the highest amounts of $\mathrm{Ni}$, whereas Omu.1 and Omu.2 samples showed, for most 
Table 3

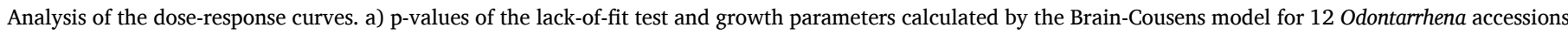

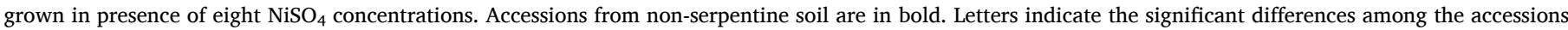

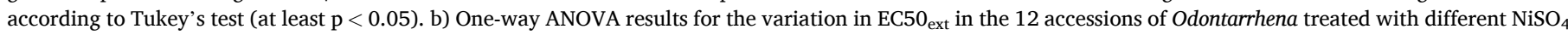

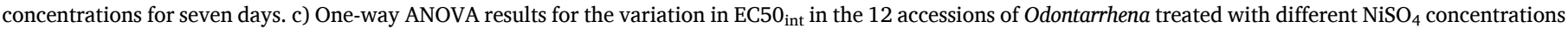
for seven days.

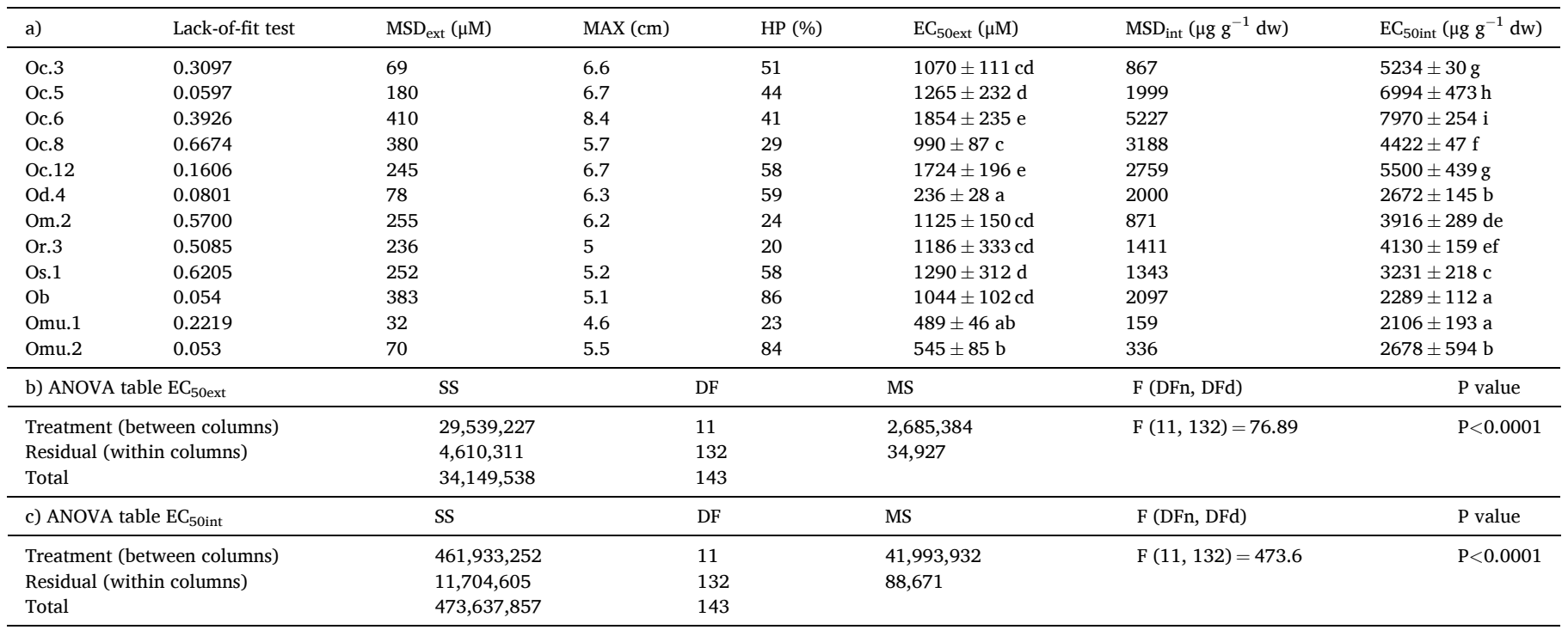

Table 4

Results of the linear regression analyses performed to investigate the relationships between the hormetic and tolerance parameters, and between them and the Ni concentration in soils and plant of origin $(*<0.05, * * \mathrm{p}<0.01)$.

\begin{tabular}{|c|c|c|c|c|c|}
\hline & $\mathrm{MSD}_{\text {ext }}$ & HP & $\mathrm{EC}_{50 \mathrm{ext}}$ & $\mathrm{MSD}_{\text {int }}$ & $\mathrm{EC}_{50 \text { int }}$ \\
\hline $\mathrm{MSD}_{\text {ext }}$ & - & & & & \\
\hline HP & $\mathrm{ns}$ & - & & & \\
\hline $\mathrm{EC}_{50 \mathrm{ext}}$ & $*$ & ns & - & & \\
\hline$M D_{\text {int }}$ & $* *$ & ns & $*$ & - & \\
\hline $\mathrm{EC}_{50 \mathrm{int}}$ & ns & ns & $* *$ & $*$ & - \\
\hline [Ni] soil & $\mathrm{ns}$ & ns & $\mathrm{ns}$ & ns & ns \\
\hline [Ni] shoot & $\mathrm{ns}$ & ns & $\mathrm{ns}$ & $*$ & $*$ \\
\hline [Ni] root & ns & ns & ns & * & $* *$ \\
\hline
\end{tabular}

concentrations used and in all three different plant compartments, the lowest values of metal concentration.

Relationships between $\mathrm{Ni}$ in roots and shoots among the accessions were analysed at $1000 \mu \mathrm{M} \mathrm{NiSO}_{4}$, due to the death of Omu.1 and Omu.2 samples at the two highest concentrations. The Ni concentration in shoots and root symplast correlated in a linear positive way $(r=0.791$, $\mathrm{p}<0.01$ ), with the Oc. 5 and Oc. 6 plants showing the highest values of $\mathrm{Ni}$ accumulation for both roots and shoots, and the Om.2, Or.3, Ob and Omu.1 accessions the lowest ones. No relation between the apoplastic $\mathrm{Ni}$ concentration and the two other compartments was found.

Accumulation data were entered in the Brain-Cousens model to calculate hormetic and tolerance parameters on the basis of also internal $\mathrm{Ni}$ concentration $\left(\mathrm{MSD}_{\text {int }}\right.$ and EC50 $0_{\text {int }}$, Table 3$)$. The esteemed amounts of $\mathrm{MSD}_{\text {int }}$ ranged from ca. $160 \mu \mathrm{g} \mathrm{Ni} \mathrm{g}{ }^{-1}$ d.w. for Omu. 1 to ca. $5200 \mu \mathrm{g} \mathrm{Ni}$

Table 5

a) Nickel accumulation ( $\mu \mathrm{g} \mathrm{g}^{-1}$ d.w.) in the root apoplast of the 12 accessions of Odontarrhena treated with eight $\mathrm{NiSO}_{4}$ concentrations for seven days. Letters indicate the significant differences among the accessions according to the Tukey's test (at least $\mathrm{p}<0.05$ ). Values are means of 12 replicates \pm standard deviation. $b$ ) Two-way ANOVA results for the variation in root apoplastic Ni concentration in the 12 accessions of Odontarrhena treated with different $\mathrm{NiSO}_{4}$ concentrations for seven days. Accessions from non-serpentine soil are in bold. Some data from Omu.1 and Omu.2 were missing because those accessions did not survive at the highest concentrations used.

\begin{tabular}{|c|c|c|c|c|c|c|c|c|}
\hline \multicolumn{9}{|c|}{ a) Ni concentration in root apoplast } \\
\hline $\mathrm{NiSO}_{4}(\mu \mathrm{M})$ & 0 & 50 & 150 & 250 & 500 & 1000 & 2000 & 3000 \\
\hline Oc. 3 & $41 \pm 27 \mathrm{bcd}$ & $483 \pm 106 c$ & $1003 \pm 228 \mathrm{e}$ & $1094 \pm 484 \mathrm{de}$ & $1222 \pm 817$ bc & $3612 \pm 558$ e & $4195 \pm 1099$ e & $4596 \pm 1282 \mathrm{e}$ \\
\hline Oc.5 & $50 \pm 28 d$ & $1044 \pm 71 \mathrm{e}$ & $1221 \pm 217 \mathrm{e}$ & $1418 \pm 313 \mathrm{f}$ & $1702 \pm 367 \mathrm{de}$ & $1818 \pm 390$ bc & $2213 \pm 345 \mathrm{bc}$ & $2270 \pm 426 \mathrm{abc}$ \\
\hline Oc.6 & $45 \pm 31 \mathrm{~cd}$ & $176 \pm 74 \mathrm{ab}$ & $488 \pm 258 \mathrm{bcd}$ & $630 \pm 301 \mathrm{bc}$ & $779 \pm 289 \mathrm{ab}$ & $2360 \pm 1068 \mathrm{~cd}$ & $4222 \pm 1365$ e & $4405 \pm 1022 \mathrm{e}$ \\
\hline Oc.8 & $23 \pm 7$ abc & $92 \pm 40 \mathrm{a}$ & $734 \pm 101 \mathrm{~d}$ & $1035 \pm 168 \mathrm{de}$ & $3396 \pm 197 \mathrm{f}$ & $3360 \pm 293$ e & $3304 \pm 381 \mathrm{~d}$ & $3097 \pm 606 \mathrm{~d}$ \\
\hline Oc.12 & $21 \pm 9 \mathrm{ab}$ & $112 \pm 91 \mathrm{ab}$ & $158 \pm 36 \mathrm{a}$ & $392 \pm 41 \mathrm{ab}$ & $621 \pm 101 \mathrm{a}$ & $748 \pm 125$ a & $1630 \pm 187 \mathrm{ab}$ & $1803 \pm 201 \mathrm{ab}$ \\
\hline Od.4 & $33 \pm 17 \mathrm{abc}$ & $801 \pm 241$ & $1109 \pm 394 \mathrm{e}$ & $1220 \pm 276$ ef & $2125 \pm 346$ e & $2178 \pm 388 \mathrm{bcd}$ & $2236 \pm 630 \mathrm{bc}$ & $2465 \pm 506$ bcd \\
\hline $\mathrm{Om} .2$ & $14 \pm 9 \mathrm{a}$ & $415 \pm 217 c$ & $563 \pm 208 \mathrm{~cd}$ & $894 \pm 241 \mathrm{~cd}$ & $1123 \pm 338 \mathrm{bc}$ & $1715 \pm 297 b$ & $1977 \pm 229 \mathrm{abc}$ & $2123 \pm 206 a b c$ \\
\hline Or.3 & $39 \pm 8 \mathrm{bcd}$ & $116 \pm 41 \mathrm{ab}$ & $325 \pm 62 \mathrm{abc}$ & $670 \pm 97 \mathrm{bc}$ & $967 \pm 102 \mathrm{ab}$ & $1685 \pm 140 \mathrm{~b}$ & $1785 \pm 136 \mathrm{ab}$ & $1769 \pm 121 \mathrm{ab}$ \\
\hline Os.1 & $24 \pm 4 \mathrm{abc}$ & $192 \pm 35 \mathrm{ab}$ & $726 \pm 134 \mathrm{~d}$ & $1178 \pm 160$ def & $1453 \pm 275 \mathrm{~cd}$ & $1695 \pm 176 b$ & $2650 \pm 228 \mathrm{~cd}$ & $2753 \pm 176 \mathrm{~cd}$ \\
\hline $\mathrm{Ob}$ & $19 \pm 7 \mathrm{ab}$ & $169 \pm 56 \mathrm{ab}$ & $326 \pm 66 \mathrm{abc}$ & $563 \pm 87 \mathrm{ab}$ & $907 \pm 109 \mathrm{ab}$ & $974 \pm 98 \mathrm{a}$ & $1209 \pm 209 \mathrm{a}$ & $1569 \pm 321 \mathrm{a}$ \\
\hline Omu.1 & $16 \pm 6 \mathrm{a}$ & $191 \pm 17 \mathrm{ab}$ & $277 \pm 38 \mathrm{ab}$ & $310 \pm 25$ a & $550 \pm 71$ a & $3200 \pm 234$ e & - & - \\
\hline Omu.2 & $27 \pm 8 \mathrm{abc}$ & $335 \pm 79 \mathrm{bc}$ & $387 \pm 61 \mathrm{abc}$ & $553 \pm 105 \mathrm{ab}$ & $1212 \pm 255 \mathrm{bc}$ & $2586 \pm 196 \mathrm{~d}$ & - & - \\
\hline \multicolumn{2}{|c|}{ b) Two-way ANOVA table } & \multicolumn{2}{|l|}{ SS } & $\mathrm{DF}$ & MS & \multicolumn{2}{|c|}{ F (DFn, DFd) } & $P$ value \\
\hline \multicolumn{2}{|l|}{ Accessions } & \multicolumn{2}{|c|}{$88,404,497$} & 11 & $8,036,772$ & \multicolumn{2}{|c|}{$F(11,792)=124.8$} & $\mathrm{P}<0.0001$ \\
\hline Treatments & & \multicolumn{2}{|c|}{$422,940,861$} & 5 & $84,588,172$ & \multicolumn{2}{|c|}{$F(5,792)=1314$} & $\mathrm{P}<0.0001$ \\
\hline Interaction & & \multicolumn{2}{|c|}{$146,981,127$} & 55 & $2,672,384$ & \multicolumn{2}{|c|}{$F(55,792)=41.51$} & $\mathrm{P}<0.0001$ \\
\hline Residual & & \multicolumn{2}{|c|}{$50,985,682$} & 792 & 64,376 & & & \\
\hline
\end{tabular}


Table 6

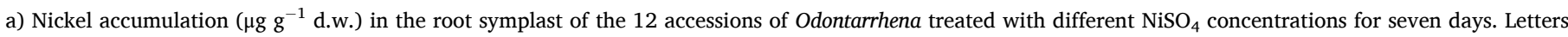

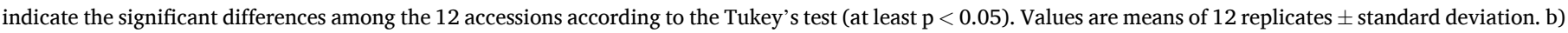

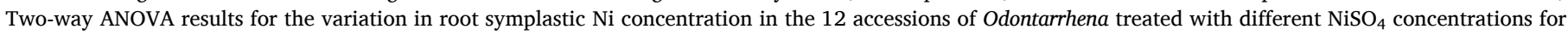

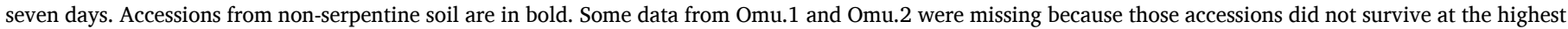
concentrations used.

\begin{tabular}{|c|c|c|c|c|c|c|c|c|}
\hline \multicolumn{9}{|c|}{ a) Ni concentration in root symplast } \\
\hline $\mathrm{NiSO}_{4}(\mu \mathrm{M})$ & 0 & 50 & 150 & 250 & 500 & 1000 & 2000 & 3000 \\
\hline Oc. 3 & $115 \pm 20 c$ & $756 \pm 33 \mathrm{~cd}$ & $1356 \pm 102 \mathrm{fg}$ & $3038 \pm 295 \mathrm{e}$ & $4965 \pm 483 \mathrm{e}$ & $5239 \pm 822 \mathrm{f}$ & $6807 \pm 508 c$ & $7453 \pm 349 c$ \\
\hline Oc. 5 & $25 \pm 6 \mathrm{a}$ & $347 \pm 34 \mathrm{ab}$ & $1549 \pm 271 \mathrm{~g}$ & $3034 \pm 516$ e & $6238 \pm 907 \mathrm{f}$ & $6885 \pm 683 \mathrm{~g}$ & $7233 \pm 401 c$ & $7330 \pm 644 \mathrm{c}$ \\
\hline Oc. 6 & $23 \pm 18 \mathrm{a}$ & $482 \pm 49 \mathrm{ab}$ & $1135 \pm 108 \mathrm{de}$ & $2829 \pm 393$ e & $6571 \pm 873 \mathrm{f}$ & $7143 \pm 553 \mathrm{~g}$ & $8192 \pm 557 d$ & $10,343 \pm 513 d$ \\
\hline Oc. 8 & $18 \pm 3 \mathrm{a}$ & $975 \pm 72 d$ & $1325 \pm 77$ ef & $2129 \pm 121 \mathrm{~d}$ & $4142 \pm 147 d$ & $4451 \pm 223 \mathrm{de}$ & $8453 \pm 148 d$ & $10,138 \pm 150 d$ \\
\hline Oc.12 & $57 \pm 21 \mathrm{~b}$ & $1779 \pm 259$ e & $2109 \pm 143 \mathrm{~h}$ & $2790 \pm 148$ e & $3659 \pm 321 \mathrm{~d}$ & $4825 \pm 399$ ef & $5741 \pm 715 b$ & $6473 \pm 435 b$ \\
\hline Od.4 & $104 \pm 63 c$ & $1849 \pm 594$ e & $2397 \pm 248 \mathrm{i}$ & $2828 \pm 634$ e & $3601 \pm 540 \mathrm{~d}$ & $4448 \pm 853 \mathrm{de}$ & $5989 \pm 465 b$ & $5464 \pm 315$ a \\
\hline $\mathrm{Om} .2$ & $32 \pm 19 \mathrm{ab}$ & $492 \pm 96 \mathrm{abc}$ & $774 \pm 193 \mathrm{bc}$ & $852 \pm 206 \mathrm{a}$ & $1778 \pm 194 \mathrm{ab}$ & $3188 \pm 439 \mathrm{bc}$ & $4761 \pm 385 \mathrm{a}$ & $5206 \pm 266 \mathrm{a}$ \\
\hline Or.3 & $27 \pm 4 \mathrm{ab}$ & $572 \pm 73$ bc & $1263 \pm 147$ ef & $1434 \pm 92 \mathrm{c}$ & $2015 \pm 121 \mathrm{ab}$ & $3776 \pm 332 \mathrm{~cd}$ & $4557 \pm 436 \mathrm{a}$ & $6074 \pm 317 b$ \\
\hline Os.1 & $40 \pm 18 \mathrm{ab}$ & $358 \pm 53 \mathrm{ab}$ & $959 \pm 175 \mathrm{~cd}$ & $1330 \pm 292 b c$ & $2855 \pm 405 c$ & $4136 \pm 501 d$ & $4561 \pm 655 \mathrm{a}$ & $5324 \pm 644$ a \\
\hline $\mathrm{Ob}$ & $107 \pm 21 \mathrm{c}$ & $288 \pm 41 \mathrm{a}$ & $665 \pm 55 \mathrm{ab}$ & $1280 \pm 110 b c$ & $1703 \pm 223 \mathrm{a}$ & $2323 \pm 210 \mathrm{a}$ & $4444 \pm 342 \mathrm{a}$ & $6415 \pm 553 b$ \\
\hline Omu.1 & $36 \pm 6 \mathrm{ab}$ & $228 \pm 31 \mathrm{a}$ & $490 \pm 75 \mathrm{a}$ & $1157 \pm 98 a b c$ & $2140 \pm 187 \mathrm{ab}$ & $2683 \pm 202 a b$ & - & - \\
\hline Omu.2 & $38 \pm 8 \mathrm{ab}$ & $281 \pm 80 \mathrm{a}$ & $651 \pm 61 \mathrm{ab}$ & $993 \pm 105 \mathrm{ab}$ & $2406 \pm 255 \mathrm{bc}$ & $3191 \pm 196 \mathrm{bc}$ & - & - \\
\hline \multicolumn{2}{|c|}{ b) Two-way ANOVA table } & \multicolumn{2}{|l|}{ SS } & DF & MS & \multicolumn{2}{|c|}{$\mathrm{F}(\mathrm{DFn}, \mathrm{DFd})$} & $\mathrm{P}$ value \\
\hline Accessions & & \multicolumn{2}{|c|}{$451,120,782$} & 11 & $41,010,980$ & \multicolumn{2}{|c|}{$F(11,792)=393.1$} & $\mathrm{P}<0.0001$ \\
\hline Treatments & & \multicolumn{2}{|c|}{$2,002,764,863$} & 5 & $400,552,973$ & \multicolumn{2}{|c|}{$F(5,792)=3840$} & $\mathrm{P}<0.0001$ \\
\hline Interaction & & \multicolumn{2}{|c|}{$416,871,947$} & 55 & $7,579,490$ & \multicolumn{2}{|c|}{$F(55,792)=72.66$} & $\mathrm{P}<0.0001$ \\
\hline Residual & & \multicolumn{2}{|c|}{$82,617,282$} & 792 & 104,315 & & & \\
\hline
\end{tabular}

Table 7

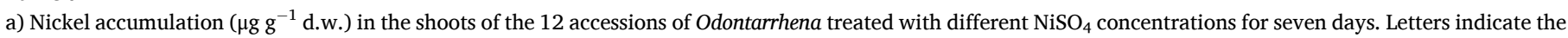

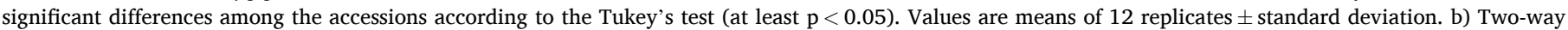

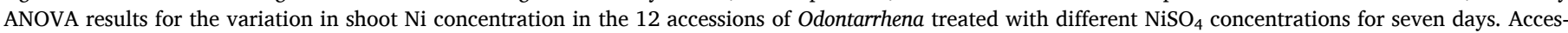

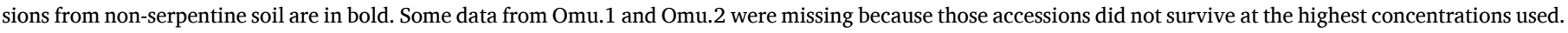

\begin{tabular}{|c|c|c|c|c|c|c|c|c|}
\hline \multicolumn{9}{|c|}{ a) Ni concentration in shoot } \\
\hline $\mathrm{NiSO}_{4}(\mu \mathrm{M})$ & 0 & 50 & 150 & 250 & 500 & 1000 & 2000 & 3000 \\
\hline Oc. 3 & $402 \pm 99 \mathrm{e}$ & $2406 \pm 466$ ef & $3220 \pm 527 \mathrm{fgh}$ & $4324 \pm 593 d$ & $5849 \pm 485 \mathrm{f}$ & $6822 \pm 1057 \mathrm{de}$ & $7615 \pm 758 \mathrm{abc}$ & $8110 \pm 1440 b$ \\
\hline Oc. 5 & $75 \pm 25 a b c$ & $1390 \pm 69 b c$ & $2770 \pm 205$ ef & $4452 \pm 298 d$ & $7940 \pm 332 \mathrm{~h}$ & $8703 \pm 370 \mathrm{f}$ & $9445 \pm 338 \mathrm{~cd}$ & $9599 \pm 405 \mathrm{~cd}$ \\
\hline Oc. 6 & $243 \pm 90 \mathrm{~d}$ & $1622 \pm 637 \mathrm{bcd}$ & $3721 \pm 799 \mathrm{~h}$ & $6443 \pm 1072 \mathrm{f}$ & $6848 \pm 901 \mathrm{~g}$ & $7180 \pm 912 \mathrm{e}$ & $7806 \pm 546 \mathrm{abc}$ & $11,094 \pm 1399 \mathrm{def}$ \\
\hline Oc. 8 & $133 \pm 44 \mathrm{bcd}$ & $1981 \pm 242 \mathrm{de}$ & $3108 \pm 364 \mathrm{fgh}$ & $4439 \pm 436 \mathrm{~d}$ & $5273 \pm 549$ ef & $6182 \pm 912 \mathrm{~cd}$ & $11,400 \pm 2083 \mathrm{e}$ & $12,058 \pm 2136$ ef \\
\hline Oc.12 & $47 \pm 17 \mathrm{abc}$ & $2819 \pm 365 \mathrm{f}$ & $3414 \pm 551 \mathrm{gh}$ & $5161 \pm 600 \mathrm{e}$ & $5403 \pm 740$ ef & $6783 \pm 580 \mathrm{de}$ & $6424 \pm 645 \mathrm{ab}$ & $6542 \pm 672 \mathrm{a}$ \\
\hline Od.4 & $192 \pm 37 \mathrm{~d}$ & $2828 \pm 368 \mathrm{f}$ & $3163 \pm 293 \mathrm{fgh}$ & $4619 \pm 518 \mathrm{de}$ & $5710 \pm 569$ ef & $6014 \pm 377 \mathrm{~cd}$ & $7358 \pm 431 \mathrm{ab}$ & $8473 \pm 641$ bc \\
\hline Om.2 & $414 \pm 214 \mathrm{e}$ & $1899 \pm 987$ cde & $2396 \pm 919 \mathrm{de}$ & $2571 \pm 261 \mathrm{~b}$ & $3470 \pm 507 \mathrm{ab}$ & $4484 \pm 640 \mathrm{~b}$ & $10,165 \pm 3456 \mathrm{de}$ & $12,706 \pm 2604 \mathrm{f}$ \\
\hline Or.3 & $407 \pm 70 \mathrm{e}$ & $1378 \pm 163 b c$ & $2809 \pm 183$ efg & $3433 \pm 208 c$ & $4164 \pm 351 \mathrm{bc}$ & $5257 \pm 523 b c$ & $6040 \pm 459 \mathrm{a}$ & $7361 \pm 2282 \mathrm{ab}$ \\
\hline Os.1 & $490 \pm 76 \mathrm{e}$ & $1341 \pm 212 b c$ & $2858 \pm 344$ efg & $3015 \pm 423 b c$ & $4344 \pm 650 \mathrm{~cd}$ & $6188 \pm 783 \mathrm{~cd}$ & $8040 \pm 938$ bc & $10,532 \pm 1288 \mathrm{cde}$ \\
\hline $\mathrm{Ob}$ & $149 \pm 46 \mathrm{~cd}$ & $1082 \pm 169 \mathrm{ab}$ & $1780 \pm 272 \mathrm{~cd}$ & $3199 \pm 504 \mathrm{bc}$ & $3735 \pm 358 \mathrm{bc}$ & $4785 \pm 634 \mathrm{~b}$ & $6585 \pm 1142 \mathrm{ab}$ & $11,412 \pm 1682 \mathrm{def}$ \\
\hline Omu.1 & $36 \pm 17 \mathrm{ab}$ & $533 \pm 4 a$ & $1102 \pm 90 \mathrm{a}$ & $1499 \pm 143 \mathrm{a}$ & $2897 \pm 215 \mathrm{a}$ & $3380 \pm 577 a$ & - & - \\
\hline Omu.2 & $18 \pm 7 \mathrm{a}$ & $\begin{array}{l}750 \pm 103 \\
\mathrm{a}\end{array}$ & $1736 \pm 154 \mathrm{bc}$ & $2814 \pm 255 \mathrm{bc}$ & $5042 \pm 680$ de & $6705 \pm 758 \mathrm{de}$ & - & - \\
\hline b) Two-way $A$ & OVA table & SS & & DF & MS & & n, DFd) & $P$ value \\
\hline Accessions & & 543,88 & & 11 & $49,444,522$ & & $792)=202.7$ & $\mathrm{P}<0.0001$ \\
\hline Treatments & & $3,371,8$ & 561 & 5 & $674,365,912$ & & $792)=2764$ & $\mathrm{P}<0.0001$ \\
\hline Interaction & & 383,516 & & 55 & $6,973,025$ & & ,792) $=28.58$ & $\mathrm{P}<0.0001$ \\
\hline Residual & & 193,233 & & 792 & 243,982 & & & \\
\hline
\end{tabular}

$\mathrm{g}^{-1}$ d.w. for Oc. 6 plants. The values of $\mathrm{EC} 50_{\text {int }}$ varied from ca. $2100 \mu \mathrm{g}$ $\mathrm{Ni} \mathrm{g}^{-1}$ d.w. for Omu. 1 to ca. $8000 \mu \mathrm{g} \mathrm{Ni}{ }^{-1}$ d.w. for Oc. 6 plants, with significant differences among the accessions.

Significant positive relationships were found between $\mathrm{MSD}_{\text {ext }}$ and MSD $_{\text {int }}(\mathrm{r}=0.746, \mathrm{p}<0.01)$ and between the latter and $\mathrm{EC} 50_{\mathrm{ext}}$ $(\mathrm{r}=0.629, \mathrm{p}<0.05)$. The $\mathrm{EC} 50_{\text {int }}$ values were significantly related to $\mathrm{EC50}_{\text {ext }}(r=0.764, \mathrm{p}<0.01)$ and $\mathrm{MSD}_{\text {int }}(\mathrm{r}=0.677, \mathrm{p}<0.05)$, whereas no relation was detected with the other parameters of the dose-response curve. Moreover, $\mathrm{MSD}_{\text {int }}$ and $\mathrm{EC} \mathrm{O}_{\text {int }}$ were positively related to Ni concentrations in roots $(\mathrm{r}=0679 \mathrm{p}<0.05$ and $\mathrm{r}=0.758, \mathrm{p}<0.01$ respectively) and shoots ( $\mathrm{r}=0.706, \mathrm{p}<0.05$ and $\mathrm{r}=0.585, \mathrm{p}<0.05$ respectively) of the native plants from the field. No relation was found between $\mathrm{MSD}_{\text {int }}$ and EC50 $0_{\text {int }}$ and the concentration of $\mathrm{Ni}$ in the soil of origin (Table 4).

\section{Discussion}

\subsection{High metal requirement in all accessions and positive relation with $\mathrm{Ni}$ tolerance}

Our analysis of $\mathrm{Ni}$ effect on plant growth revealed a significant general increase in root length increment in a low-dose zone (from 50 to $500 \mu \mathrm{M})$. Such stimulatory Ni concentrations were similar to those observed in other studies reporting the same phenomenon in hyperaccumulators (see for example Krämer et al., 1996; Küpper et al., 2001; Galardi et al. 2007), and were unexpectedly high when considering the low toxicity threshold of $\mathrm{Ni}$ (below $5 \mu \mathrm{M}$, Marschner, 1995). Actually, all the dose-response curves fitted significantly to the hormesis-dedicated model of Brain-Cousens (Brain and Cousens, 1989), whereas the four-parameter logistic response function gave a substantial lack-of-fit 
result. In addition, the magnitude of the stimulating effect (HP) showed values not lower than ca. $20 \%$, thus well above the minimum value of $10 \%$ required to prove the presence of an hormetic effect (Calabrese and Blain, 2009). Therefore, the Ni-induced hormetic effect appears as a common trait in the Odontarrhena accessions studied here. Based on the parameters $\mathrm{MSD}_{\text {ext }}$ and $\mathrm{HP}$, each accession showed different values at which the maximum stimulatory effect occurred, but without any relation with the magnitude of the effect itself (f.i. the accessions with the highest MSD did not show the highest stimulation in growth, indicated by HP). Concerning the EC50 $0_{\text {ext }}$ values, their ten-fold spanning and the significant differences among some accessions pointed to very variable levels of Ni tolerance in the Odontarrhena plants here studied. Notably, the linear positive relationship between $\mathrm{MSD}_{\text {ext }}$ and EC50 ext suggested that the accessions with higher $\mathrm{Ni}$ requirements for optimal growth were also the most tolerant ones. To the best of our knowledge, this is the first report of such a quantitative relationship between metal requirement and metal tolerance in $\mathrm{Ni}$ hyperaccumulating plants.

Interestingly, the populations of the facultative serpentinophyte $O$. chalcidica showed significantly different values of $\mathrm{EC} \mathrm{C}_{\mathrm{ext}}$, but variability in Ni tolerance was not related to a possible effect of soil type. Actually, the plants of $O$. chalcidica from the non-serpentine type locality in the Chalkidiki peninsula of Greece showed the same level of $\mathrm{Ni}$ tolerance as the conspecific serpentine populations and the same Niinduced stimulation on growth. This result was unexpected since the population was from a non Ni-enriched soil (Table 1), thus supposing a higher Ni sensitivity in such plants in respect to the serpentine ones. Therefore, Ni tolerance in $O$. chalcidica is likely a species-wide trait, as proposed in other species and metals, such as Noccaea caerulescens for $\mathrm{Zn}$ (Pollard et al., 2002; Manara et al., 2020). Additional relevant results came from the two non-serpentine populations of $O$. muralis. These were incapable to survive in the high-dose zone, but showed the same $\mathrm{Ni}$-induced stimulatory response of the other accessions, though only at the lowest Ni concentration in the growth medium. Moreover, these plants displayed $\mathrm{EC} 50_{\text {ext }}$ values not significantly different from some of the other studied plants, thus indicating a similar Ni tolerance. This finding suggests that tolerance can occur even in Odontarrhena taxa that are not specialized to serpentine soils, probably due to a genus-wide pre-adaptation that could also concur to explain the extensive occurrence of Ni-accumulation ability across the genus (Reeves et al., 2018).

\subsection{Relation between Ni tolerance and accumulation}

Regarding Ni accumulation, metal shoot concentration in all plants was always higher than root concentration, as typical of hyperaccumulating plants (Deng et al., 2018). Furthermore, the accessions with the highest root $\mathrm{Ni}$ amounts displayed also the highest shoot ones, thus suggesting the absence of exclusion mechanisms during translocation. Root metal concentration was always higher in the symplast than in the apoplast, a feature that would deserve more research in Odontarrhena, since a low ability of the root cell wall to immobilize the metal could contribute to the increased Ni uptake in hyperaccumulators. In contrast, excluders present an opposite strategy that prevents the entry of the metal into the root cells and its subsequent translocation to the shoots (Corso and García de la Torre, 2020).

Noteworthy, the plant Ni concentrations at which the accessions showed optimal growth ( MSD $_{\text {int }}$ ), were several magnitude orders higher than the esteemed tissue amount of $\mathrm{Ni}$ as a micronutrient $\left(0.1 \mu \mathrm{g} \mathrm{g}^{-1} \mathrm{~d}\right.$. w. or lower, Brown et al., 1987; Gerendas et al., 1999). The positive relationship between the parameters $\mathrm{MSD}_{\text {ext }}$ and $\mathrm{MSD}_{\text {int }}$ suggested that the plants requiring the highest concentrations in the substrate were those requiring the highest concentrations also inside their tissues. The latter accessions were also the more tolerant ones, considering the significant relation between $\mathrm{MSD}_{\text {int }}$ and both the tolerance to external $\mathrm{Ni}$ concentration $\left(\mathrm{EC}_{50 \mathrm{ext}}\right.$ ) and the tolerance to the amount of Ni accumulated inside the cells $\left(\mathrm{EC}_{50 \mathrm{int}}\right)$. Furthermore, a significant relation was found between $\mathrm{EC}_{50 \mathrm{ext}}$ and $\mathrm{EC}_{50 \mathrm{int}}$ corroborating the positive link between Ni tolerance and accumulation. Therefore, at least for roots, the more tolerant plants have likely acquired enhanced tolerance and capacity to sequester $\mathrm{Ni}$ in their tissues, thus explaining the positive link between Ni requirement and tolerance. Accordingly, the Ni-mediated stimulation on the growth of the studied plants could be expected to be generated by a hyperaccumulation-mediated $\mathrm{Ni}$ cytosolic depletion in the low-dose zone.

Our findings highlighted broad variability in $\mathrm{Ni}$ accumulation capacity among the studied accessions. As for tolerance, no differences were found in the response of $O$. chalcidica populations in relation to the soil of origin. In fact, the population from the non-serpentine type locality in Greece was capable not only to tolerate but also to hyperaccumulate $\mathrm{Ni}$ as the serpentine populations did, thus showing hyperaccumulation to be a species-wide trait in this taxon. Similar evidence for constitutive $\mathrm{Ni}$ hyperaccumulation came from early studies on species of Noccaea (Reeves and Baker, 1984; Boyd and Martens, 1998) and was more recently supposed also for the facultative serpentinophyte O. serpyllifolia (Pollard et al., 2014). Moreover, the native plants of this O. chalcidica population showed Ni concentration at hyperaccumulation level ( $>1000 \mu \mathrm{g} \mathrm{g}^{-1}$ d.w.), despite the low metal amount in the substrate (Table 1). So far, Ni-hyperaccumulation outside serpentine outcrops has never been reported, pointing to the need of more research to clarify whether this species could actually hyperaccumulate the metal even when growing on natural not Ni-enriched soil. On the contrary, native plants of $O$. muralis showed low Ni concentrations, as well as the soils on which they were growing (Table 1 ). These plants were the only ones that, in the best conditions for growth, did not reach the Ni-hyperaccumulation threshold, even though Ni was much higher than the toxicity limits for plants not adapted to this metal (Kabata-Pendias and Pendias, 2001). Nonetheless, and despite metal levels generally lower than in the other accessions, $O$. muralis displayed the hyperaccumulation features described above for the other studied plants. Therefore, the non-serpentine populations of this species are likely to possess the necessary physiological background to accumulate $\mathrm{Ni}$, with maximum values approaching the limits of hyperaccumulation. All these findings encourage to extend the research to the other populations of this species and to other still unknown Odontarrhena taxa, to assess whether the physiological ability both to tolerate and to accumulate $\mathrm{Ni}$ is a genus-wide property in these plants. Nevertheless, the facultative serpentinophyte $O$. sibirica has been recently shown to be incapable of $\mathrm{Ni}$ hyperaccumulation, thus suggesting that the ability of hyperaccumulation can also be lost (Bettarini et al., 2020). Previous studies have reported that some "Alyssum" species are physiologically incapable to tolerate and accumulate $\mathrm{Ni}$ as compared to the hyperaccumulating ones (see for example Morrison et al., 1980; Brooks et al., 1981; Krämer et al., 1996), but those results were biased by the wrong inclusion of the hyperaccumulating species, actually Odontarrhena, in the same genus of the excluding species, actually Alyssum.

\subsection{Are Ni tolerance and accumulation related to Ni concentration in soils and plants of origin?}

Tolerance to external Ni concentration $\left(\mathrm{EC} 50_{\mathrm{ext}}\right)$ did not show any relationship with data on field collected samples. Therefore, nor the distribution pattern of the accessions on outcrops with different metal amounts, neither the levels of $\mathrm{Ni}$ in the plants growing on them, were apparently determined by differences in metal tolerance among the samples. Furthermore, there was also no relationship between the accumulation ability (expressed by EC50 ${ }_{\text {int }}$ ) and Ni concentration in the native sites, as reported for populations of $O$. bertolonii (Galardi et al., 2007) and O. lesbiaca (Adamidis et al., 2014). The latter study took into consideration the soil $\mathrm{Ni}$ bioavailable fraction, thus suggesting that neither its determination can be useful to find such still elusive link. On the other hand, our data showed a positive relationship between the $\mathrm{Ni}$ concentrations in the native plants and the accumulation capacity, and also with the plant internal concentration for optimal growth. 
Hence, the general idea that the less tolerant taxa occur on the metalliferous soils with lower metal levels, with adaptive evolution of tolerance in response to soil toxicity (Pollard et al., 2002), does not fit results from our Odontarrhena accessions, considering both the tolerance to the external Ni concentration and to that inside the plants. Nonetheless, the plant Ni concentration in nature seemed to be related to the different accumulation capacity of the accessions, in the light of the significant relationships showed by $\mathrm{EC} \mathrm{O}_{\text {int }}$ with field plant samples.

\section{Conclusions}

In conclusion, our quantitative approach to the study of $\mathrm{Ni}$ on plant response showed that, at relatively low doses, the metal exerted a stimulating effect on growth directly related to the degree of metal tolerance and accumulation in all the studied Odontarrhena accessions. Nickel tolerance and hyperaccumulation were highly variable and there was a quantitative direct relationship between them. The differences in accumulation capacity displayed a direct relationship with the Ni concentration present in the plants inhabiting the outcrops of origin.

In addition, $O$. chalcidica showed genuine hyperaccumulating behavior even outside serpentine soil, suggesting Ni hyperaccumulation to a be a species-wide trait. On the other hand, $O$. muralis, at least for its non-serpentine populations, was proved to tolerate the metal at the same level of the serpentine Odontarrhena but it cannot be considered a hyperaccumulator. Further studies on other Odontarrhena taxa and populations, especially from non-serpentine soils, are needed to assess whether $\mathrm{Ni}$ accumulation and tolerance are genus-wide traits.

\section{Author contributions}

CG and IC conceived and designed the work. IB, IC, CG and AC conducted the experiment, performed the data analysis and interpreted the data. CG wrote the manuscript, IC and FS revised it. All authors approved the manuscript.

\section{Declaration of Competing Interest}

The authors declare that they have no known competing financial interests or personal relationships that could have appeared to influence the work reported in this paper

\section{Acknowledgments}

This research was supported by funds from the University of Firenze (2016-2019)

\section{References}

Adamidis, G.C., Aloupi, M., Kazakou, E., Dimitrakopoulos, P.G., 2014. Intra-specific variation in $\mathrm{Ni}$ tolerance, accumulation and translocation patterns in the $\mathrm{Ni}$ hyperaccumulator Alyssum lesbiacum. Chemosphere 95, 496-502. https://doi.org/ 10.1016/j.chemosphere.2013.09.106.

Baker, A.J.M., Brooks, R.R., 1989. Terrestrial higher plants which hyperaccumulate metallic elements. A review of their distribution, ecology and phytochemistry. Biorecovery 1, 81-126. https://doi.org/10.1080/01904168109362867.

Bani, A., Pavlova, D., Echevarria, G., Mullaj, A., Reeves, R.D., Morel, J.L., Sulçe, S., 2010. Nickel hyperaccumulation by species of Alyssum and Thlaspi (Brassicaceae) from ultramafic soils of the Balkans. Bot. Serb. 34 (1), 3-14.

Bani, A., Imeri, A., Echevarria, G., Pavlova, D., Reeves, R.D., Morel, J.L., Sulçe, S., 2013. Nickel hyperaccumulation in the serpentine flora of Albania. Fres. Env. Bull. 22, 1792-1801.

Bazihizina, N., Colzi, I., Giorni, E., Mancuso, S., Gonnelli, C., 2015. Photosynthesizing on metal excess: copper differently induced changes in various photosynthetic parameters in copper tolerant and sensitive Silene paradoxa L. Populations. Plant Sci. 232, 67-76. https://doi.org/10.1016/j.plantsci.2014.12.015.

Bettarini, I., Colzi, I., Gonnelli, C., Pazzagli, L., Reeves, R.D., Selvi, F., 2020. Inability to accumulate $\mathrm{Ni}$ in a genus of hyperaccumulators: the paradox of Odontarrhena sibirica (Brassicaceae). Planta 252, 99. https://doi.org/10.1007/s00425-020-03507-x.

Bettarini, I., Colzi, I., Coppi, A., Falsini, S., Echevarria, G., Pazzagli, L., Selvi, F. Gonnelli, C., 2019. Unravelling soil and plant metal relationships in Albanian nickel hyperaccumulators in the genus Odontarrhena (syn. Alyssum sect. Odontarrhena,
Brassicaceae). Plant Soil 440, 135-149. https://doi.org/10.1007/s11104-01904077-y.

Boyd, R.S., Martens, S.N., 1998. Nickel hyperaccumulation in Thlaspi montanum var. montanum (Brassicaceae): a constitutive trait. Am. J. Bot. 85, 259-265.

Brooks, R.R., 1983. Biological methods of prospecting for minerals. John Wiley and Sons, New York.

Brain, P., Cousens, R., 1989. An equation to describe dose-responses where there is stimulation of growth at low doses. Weed Res. 29, 93-96. https://doi.org/10.1111/ j.1365-3180.1989.tb00845.x.

Brooks, R.R., Lee, J., Reeves, R.D., Jaffré, T., 1977. Detection of nickeliferous rocks by analysis of herbarium specimens of indicator plants. J. Geochem. Explor. 7, 49-57. https://doi.org/10.1016/0375-6742(77)90074-7.

Brooks, R.R., Shaw, S., Asensi Marfil, A., 1981. Some observations on the ecology, metal uptake and nickel tolerance of Alyssum serpyllifolium subspecies from the Iberian peninsula. Vegetatio 45, 183-188.

Brown, P.H., Welch, R.M., Cary, E.E., 1987. Nickel: a micronutrient essential for higher plants. Plant Physiol. 85, 801-803. https://doi.org/10.1104/pp.85.3.801.

Calabrese, E.J., Blain, R.B., 2009. Hormesis and plant biology. Environ. Pollut. 157, 42-48. https://doi.org/10.1016/j.envpol.2008.07.028.

Cecchi, L., Bettarini, I., Colzi, I., Coppi, A., Echevarria, G., Pazzagli, L., Bani, A., Gonnelli, C., Selvi, F., 2018. The genus Odontarrhena (Brassicaceae) in Albania: taxonomy and nickel accumulation in a critical group of metallophytes from a major serpentine hot-spot. Phytotaxa 351, 1-28. https://doi.org/10.11646/ phytotaxa.351.1.1.

Centofanti, T., Sayers, Z., Cabello-Cornejo, M.I., Kidd, P., Nishizawa, N.K., Kakei, Y., Davis, A.P., Sicher, R.C., Chaney, R.L., 2013. Xylem exudate composition and rootto-shoot nickel translocation in Alyssum species. Plant Soil 373, 59-75. https:// www.jstor.org/stable/42952471.

Colzi, I., Rocchi, S., Rangoni, M., Del Bubba, M., Gonnelli, C., 2014. Specificity of metal tolerance and use of excluder metallophytes for the phytostabilization of metal polluted soils: the case of Silene paradoxa L. Environ. Sci. Pollut. Res. 21, 10960-10969. https://doi.org/10.1007/s11356-014-3045-y.

Coppi, A., Baker, A.J.M., Bettarini, I., Colzi, I., Echevarria, G., Pazzagli, L., Gonnelli, C., Selvi, F., 2020. Population genetics of Odontarrhena (Brassicaceae) from Albania: the effects of anthropic habitat disturbance, soil and altitude on a Ni-hyperaccumulator plant group from a major serpentine hotspot. Plants 9, 1686. https://doi.org/ 10.3390 /plants9121686.

Corso, M., García de la Torre, V.S., 2020. Biomolecular approaches to understanding metal tolerance and hyperaccumulation in plants. Metallomics. https://doi.org/ 10.1039/D0MT00043D.

Deng, T.H.B., van der Ent, A., Tang, Y.T., Sterckeman, T., Echevarria, G., Morel, J.L., Qiu, R.L., 2018. Nickel hyperaccumulation mechanisms: a review on the current state of knowledge. Plant Soil 423, 1-11. https://doi.org/10.1007/s11104-0173539-8.

Galardi, F., Mengoni, A., Pucci, S., Barletti, L., Massi, L., Barzanti, R., Gabbrielli, R. Gonnelli, C., 2007. Intra-specific differences in mineral element composition in the Ni-hyperaccumulator Alyssum bertolonii: a survey of populations in nature. Environ. Exp. Bot. 60, 50-56. https://doi.org/10.1016/j.envexpbot.2006.06.010.

Gerendas, J., Polacco, J.C., Freyermuth, S.K., Sattelmacher, B., 1999. Significance of nickel for plant growth and metabolism. J. Plant Nutr. Soil Sc. 162, 241-256.

Gonnelli, C., Renella, G., 2012. Chromium and nickel. In: Alloway, B.J. (Ed.), Heavy Metals in Soils. Springer, Dordrecht, pp. 313-333.

Hanikenne, M., Talke, I.N., Haydon, M.J., Lanz, C., Nolte, A., Motte, P., Kroymann, J., Weigel, D., Krämer, U., 2008. Evolution of metal hyperaccumulation required cisregulatory changes and triplication of HMA4. Nature 453, 391-395. https://doi. org/10.1038/nature06877.

Hartvig, P., 2002. Alyssum. In: Strid, A., Tan, K. (Eds.), Flora Hellenica 2. Gantner Verlag, Ruggell, pp. 199-224.

Hoagland, D.R., Arnon, D.I., 1950. The water-culture method for growing plants with-out soil. Calif. Agric. Exp. Stn. Circ. 347, 1-39.

Kabata-Pendias, A., Pendias, H., 2001. Trace Elements in Soils and Plants, third ed. CRC, Boca Raton.

Kidd, P.S., Bani, A., Benizri, E., Gonnelli, C., Hazotte, C., Kisser, J., Konstantinou, M., Kuppens, T., Dimitris, K., Laubie, B., Malina, R., Morel, J.L., Olcay, H., Pardo, T., Pons, M.N., Prieto-Fernández, A., Puschenreiter, M., Quintela-Sabarís, C., Ridard, C., Rodríguez-Garrido, B., Rosenkranz, T., Rozpądek, P., Saad, R., Selvi, F., Simonnot, M.O., Tognacchini, A., Turnau, K., Wazny, R., Witters, N., Echevarria, G., 2018. Developing sustainable agromining systems in agricultural ultramafic soils for nickel recovery. Front. Plant Sci. 6, 44. https://doi.org/10.3389/fenvs.2018.00044.

Krämer, U., 2010. Metal hyperaccumulation in plants. Annu. Rev. Plant Biol. 61, 517-534. https://doi.org/10.1146/annurev-arplant-042809-112156.

Krämer, U., Cotterhowells, J.D., Charnock, J.M., Baker, A.J.M., Smith, J.A.C., 1996. Free histidine as a metal chelator in plants that accumulate nickel. Nature 379, 635-638.

Küpper, H., Lombi, E., Zhao, F.J., Wieshammer, G., McGrath, S.P., 2001. Cellular compartmentation of nickel in the hyperaccumulators Alyssum lesbiacum, Alyssum bertolonii and Thlaspi goesingense. J. Exp. Bot. 365, 2291-2300. https://doi.org/ 10.1093/jexbot/52.365.2291.

Manara, A., Fasani, E., Furini, A., Dal Corso, G., 2020. Evolution of the metal hyperaccumulation and hypertolerance traits. Plant Cell Environ. 1-18. https://doi. org/10.1111/pce.13821.

Marschner, H., 1995. Mineral Nutrition of Higher Plants. Academic Press, London.

Minguzzi, C., Vergnano, O., 1948. Il contenuto di nichel nelle ceneri di Alyssum bertolonii. Atti. Soc. Tosc. Sci. Nat. 55, 49-74.

Morrison, R.S., Brooks, R.R., Reeves, R.D., 1980. Nickel uptake by Alyssum species. Plant Sci. Lett. 17, 451-457. 
Nkrumah, P.N., Baker, A.J.M., Chaney, R.L., Erskine, P.D., Echevarria, G., Morel, J.L., van der Ent, A., 2016. Current status and challenges in developing nickel phytomining: an agronomic perspective. Plant Soil 406, 55-69.

Peer, W.A., Mahmoudian, M., Freeman, J.L., Lahner, B., Richards, E.L., Reeves, R.D., Murphy, A.S., Salt, D.E., 2006. Assessment of plants from the Brassicaceae family as genetic models for the study of nickel and zinc hyperaccumulation. New Phytol. 172, 248-260.

Pollard, A.J., Powell, K.D., Harper, F.A., Smith, J.A., 2002. The genetic basis of metal hyperaccumulation in plants. Crit. Rev. Plant Sci. 21, 539-566. https://doi.org/ 10.1080/0735-260291044359.

Pollard, A.J., Reeves, R.D., Baker, A.J.M., 2014. Facultative hyperaccumulation of heavy metals and metalloids. Plant Sci. 217, 8-17. https://doi.org/10.1016/j. plantsci.2013.11.011.

Poschenrieder, C., Cabot, C., Martos, S., Gallego, B., Barceló, J., 2013. Do toxic ions induce hormesis in plants? Plant Sci. 212, 15-25. https://doi.org/10.1016/j. plantsci.2013.07.012.

Reeves, R.D., Baker, A.J.M., 1984. Studies on metal uptake by plants from serpentine and non-serpentine populations of Thlaspi goesingense Hálácsy (Cruciferae). New Phytol 98, 191-204.

Reeves, R.D., Brooks, R.R., Dudley, T.R., 1983. Uptake of nickel by species of Alyssum, Bornmuellera, and other genera of old world tribus Alysseae. Taxon 32, 184-192.

Reeves, R.D., Baker, A.J.M., 2000. Metal accumulating plants. In: Raskin, I., Finsley, B.D. (Eds.), Phytoremediation of toxic metals: using plants to clean up the environment. Wiley, New York, pp. 193-229.

Reeves, R.D., Baker, A.J.M., Jaffré, T., Erskine, P.D., Echevarria, G., van der Ent, A., 2018. A global database for plants that hyperaccumulate metal and metalloid trace elements. New Phytol. 218, 407-411. https://doi.org/10.1111/nph.14907.

Ritz, C., Baty, F., Streibig, J.C., Gerhard, D., 2015. Dose-Response Analysis Using R. https://doi.org/10.1371/journal.pone.0146021.
Španiel, S., Kempa, M., Salmerón-Sánchez, E., Fuertes-Aguilar, J., Mota, J.F., AlShehbaz, I.A., German, D.A., Olšavská, K., Šingliarová, B., Zozomová-Lihová, J. et al., 2015. AlyBase: database of names, chromosome numbers, and ploidy levels of Alysseae (Brassicaceae), with a new generic concept of the tribe. Plant Syst. Evol. 301, 2463-2491.

Talke, I.N., Hanikenne, M., Kramer, U., 2006. Zinc- dependent global transcriptional control, transcriptional deregulation, and higher gene copy number for genes in metal homeostasis of the hyperaccumulator Arabidopsis halleri. Plant Physiol. 142, 147-167. https://doi.org/10.1104/pp.105.076232.

van der Ent, A., Baker, A.J.M., Reeves, R.D., Pollard, A.J., Schat, H., 2013. Hyperaccumulators of metal and metalloid trace elements: facts and fiction. Plant Soil 362. https://doi.org/10.1007/s11104-012-1287-3, 319v334.

van der Ent, A., Baker, A.J.M., Reeves, R.D., Chaney, R.L., Anderson, C.W.N., Meech, J. A., Erskine, P.D., Simonnot, M.O., Vaughan, J., Morel, J.L., Echevarria, G., Fogliani, B., Rongliang, Q., Mulligan, D.R., 2015. Agromining: farming for metals in the future? Environ. Sci. Technol. 49, 4773-4780. https://doi.org/10.1021/ es506031u.

Verbruggen, N., Hermans, C., Schat, H., 2009. Molecular mechanisms of metal hyperaccumulation in plants. New Phyt. 181, 759-776. https://doi.org/10.1111/ j.1469-8137.2008.02748.x.

Whiting, S.N., Neumann, P.M., Baker, A.J.M., 2003. Nickel and zinc hyperaccumulation by Alyssum murale and Thlaspi caerulescens (Brassicaceae) do not enhance survival and whole-plant growth under drought stress. Plant Cell Environ. 26, 351-360. https://doi.org/10.1046/j.1365-3040.2003.00959.x.

Wójcik, M., Gonnelli, C., Selvi, F., Dresler, S., Rostański, A., Vangronsveld, J., 2017. Metallophytes of serpentine and calamine soils - their unique ecophysiology and potential for phytoremediation. Adv. Bot. Res. 83, 1-42. 